\title{
POTASIUM AND MICRO FERTILIZERS APPLICATION FOR IMPROVING CASSAVA PRODUCTION HARVESTING AT 7 AND 10 MONTH AFTER PLANTING
}

\author{
Aplikasi Pupuk Kalium dan Mikro untuk Perbaikan Produksi Ubikayu \\ Saat Panen 7 dan 10 Bulan Setelah Tanam
}

Kukuh Setiawan*, M. Fajrin Najib, M. Syamsoel Hadi, Erwin Yuliadi

Department of Agronomy and Horticulture, College of Agriculture, University of Lampung

*E-mail: kukuhsetiawan38@gmail.com

\begin{abstract}
ABSTRAK
Cara panen ubikayu yang biasa dilakukan di tingkat petani adalah sekitar tanaman umur 7 bulan setelah tanam (BST). Selain itu, petani maupun pihak industri sangat jarang melakukan pemupukan kalium $(\mathrm{KCl})$ maupun unsur mikro untuk perbaikan produksi ubikayu. Hal ini akan menyebabkan penurunan produksi baik dari bobot ubi maupun kadar pati. Oleh karena itu, tujuan penelitian ini adalah untuk mengevaluasi produksi ubikayu akibat aplikasi pemupukan kalium $(\mathrm{KCl})$ dan pupuk mikro pada umur panen 7 dan 10 BST. Perlakuan disusun secara faktorial (2x2) dalam rancangan kelompok teracak lengkap (RKTL) dengan tiga ulangan sebagai kelompok. Faktor pertama adalah aplikasi dua dosis pupuk KCL, 200 dan $300 \mathrm{~kg} \mathrm{KCl} / \mathrm{ha}$. Faktor kedua adalah aplikasi dua dosis pupuk mikro, 0 dan $20 \mathrm{~kg}$ Zincmikro/ha. Hasil menunjukkan bahwa tidak ada variasi pada variabel jumlah ubi dan bobot ubi akibat pemupukan kalium dan mikro. Hal ini menggambarkan bahwa aplikasi pupuk kalium dan mikro menghasilkan jumlah ubi dan bobot ubi yang tidak berbeda. Selanjutnya, aplikasi pupuk kalium dan mikro memberikan pengaruh pada variabel pertumbuhan tajuk seperti bobot kering batang dan daun pada umur $10 \mathrm{BST}$.
\end{abstract}

Kata kunci: bobot kering batang, bobot kering daun, kalium, mikro, panen, produksi

\begin{abstract}
The harvest of cassava usually conducted by farmers in Lampung province is around 7 months after planting (MAP). Moreover, either farmers or industry cassava rarely fertilized by using potassium $(\mathrm{KCl})$ and also micro fertilizers to improve the cassava production. This condition could decrease the production both root weight and strach content. Consequently, the objective of this study was to evaluate the cassava production applied by potassium and micro fertilizers harvested at 7 and 10 MAP. Treatments were arranged by factorial (2x2) in completely randomized block design (CRBD) with three reps used as block. First factor were two levels of $\mathrm{KCl}, 200$ and $300 \mathrm{~kg} \mathrm{KCl/ha}$. Second factor was two levels of micro nutrient, 0 and $20 \mathrm{~kg}$ zincmicro nutrient/ha. The result showed that there was no variation of root number and root weight due to application of potassium and micro fertilizers. This means that root number and root weight were not significantly different applied by potassium and micro fertilizers. In addition, application of potassium and micro fertilizers could significantly influence shoot growth as stem dry weight and leaf dry weight at 10 MAP.
\end{abstract}

Keywords: harvest, leaf dry weight, micro fetilizer, potassium, production, stem dry weight 


\section{INTRODUCTION}

Lampung Province of Indonesia is one the high production of Cassava (Manihot esculenta, Crantz). This makes Lampung Province to be the central cassava production in Indonesia, approximately the harvest area of cassava was around 280 thousand ha (BPS, 2018). Based on this area, $85 \%$ was from small holder of farmers and $15 \%$ ) was from private company. The well-known issue is that farmers frequently harevst cassava at seven months after planting (MAP). This certainly decreases the cassava production both root weight and starch content. According to You et al. (2016) the optimum harvest of cassava will be at 10-12 MAP because the content of starch based on the root dry weight will be around $69-78 \%$ and those on the root fresh weight will be around $23-26 \%$. This supported by Apea-Bah et al. (2011) that the

of various $\mathrm{N}$ applications with different harvest dates had been studied by de Oliveira (2017). They reported that the maximum harvest index (HI) achieved was $75 \%$ at 266 day after emergence (DAE) in plants that received $150 \mathrm{~kg} / \mathrm{ha} \mathrm{N}$ topdressing. Moreover, Howeler (2001) stated that the application of fertilizer for cassava in Thailand and Vietnam tended to be more $\mathrm{P}$ of $0.47 \mathrm{~kg}$ ) when early harvested at 210 DAP. This means that low yield of cassava root and starch harvested at early time could be improved by adding micro nutrient fertilizer.

Study on the application of micro nutrient combined with macro nutrient fertilizers to increase cassava starch yield was conducted by Panitnok et al. (2013). They showed that in Thailand, fresh weight of storage root and starch content would increase up to $30 \%$ and $29 \%$, respectively when cassava is applied by $\mathrm{Zn}$. Additionally, Kumar (2013) explained that the application of micro nutrient in sorghum could certainly increase grain yield and also the $\mathrm{Zn}$ and Fe content in grain. Setiawan et al. (2017) showed their research result that optimum starch content of cassava will be achieved at 10-12 MAP. The next researchers supported were Prammanee et al. (2010); Baafi and Safo-Kantanka (2007) stated that yield of cassava root harvested from young cassava plant ( around 7 MAP) was absolutely low both for fresh root weight and for starch content.

The two other problems of low cassava production are that the farmers or even private company rarely or even never put macro nutrient of $\mathrm{K}$ and micro nutrient fertilizer in the field. After harvesting cassava, they frequently fertilized macro nutrient as $\mathrm{N}, \mathrm{P}$, and $\mathrm{K}$ but rarely put micro nutrient in the field. Such behavior could create problem particularly lower soil fertility resulted in lower fresh cassava root yield and starch quality. The Effect

than $\mathrm{N}$ and $\mathrm{K}$. Moreover, he also reported that $\mathrm{N}$ was more in leave; $\mathrm{K}$ was more in storage root. The information regarding micro nutrient fertilizer for enhancing cassava starch yield is apparently rare. Moreover, in Indonesia, Hadi (2010) gave information that application of micro nutrient could increase fresh weight of storage root (yield increment

the application of micro nutrient containing 5,888 ppm Fe and 1,368 ppm $\mathrm{Zn}$ could increase root fresh weight and starch granule size. In addition, Dos Santos et al. (2014) concluded that absorption of micro nutrient would be influenced by cassava age and $\mathrm{N}$ content in plant. However, absorption of $\mathrm{Fe}$ showed high concentration in leaf and storage root, as 0.45 and $0.38 \mathrm{~kg} / \mathrm{ha}$, respectively in cassava plant without fertilizer application (Howeler, 1981 and 2001).

Fageria (2009) reported that absorption of $\mathrm{Fe}$ would be high in the condition of low pH. Panitnok et.al. (2013) reported that combination of $\mathrm{Zn}, \mathrm{Mg}$ and $\mathrm{S}$ did not show the effect on storage root production but would be significant in the 
production of starch, starch content would be $28.5 \%$ when applied by $\mathrm{Zn}$ but $24.9 \%$ when applied no Zn (only $\mathrm{Mg}$ and S). Based on that You-Zhi et al. (2015) reported that there were four questions from scientist due mainly to limited proof from research result as whether high starch accumulation in storage root related to strong capacity of transport from stem part, whether high starch accumulation in storage root as a result of low efficient of starch degradation, whether glucose move via transportation far distance from stem, whether only glucose transport correlate with the ability of starch accumulation in part of storage root. To increase storage root yield, Agbaje dan Akinlosotu (2004) concluded that cassava storage root yield was 31 ton/ha when harvested at early planting and those was 44 ton/ha when harvested at late planting.

Kayode (1983) and Apea-Bah et al. (2011) suggested that the proper time for harvesting cassava would be at 12 MAP because the accumulation of dry matter and starch would be optimum at 12 MAP. Based on this, it means that cassava root yield weight and starch content will increase when cassava is harvested at 10-12 MAP. According to Zhu (2014) cassava starch has finer surface than potato starch and the more age cassava to be harvested the more granule would clearly distribute. The proper harvest time would be at 10 MAP because starch granule would evenly distribute in the root resulted in increasing starch content. It also means that high starch yield of cassava is 10 MAP. Consequently, the objective of this study was to evaluate the production of cassava harvested at 7 and 10 MAP under the application of potassium and micro fertilizers.

\section{RESEARCH METHODS}

This study was conducted on Desa Sukanegara, Kecamatan Tanjung Bintang, Kabupaten Lampung Selatan and on Laboratory of Agronomy, College of Agriculture, University of Lampung from
September 2017 to August 2018. The soil character was sandy loam of red podzolic.

Cassava clone used in this study was BW1 with five buds of $25 \mathrm{~cm}$ stem. The fertilizers of $200 \mathrm{~kg}$ urea, $150 \mathrm{~kg}$ TSP and $200 \mathrm{~kg} \mathrm{KCl} / \mathrm{ha}$ were used as source of $45 \%$ $\mathrm{N}$ urea, $45 \% \mathrm{P}_{2} \mathrm{O}_{5}$ TSP $\left(\mathrm{Ca}\left(\mathrm{H}_{2} \mathrm{PO}_{4}\right)\right.$, and $60 \% \mathrm{~K}_{2} \mathrm{O} \mathrm{KCl}$, respectively. The micro nutrient of ZincMicro containing 5,880.31 ppm Fe, 482.61 ppm $\mathrm{Mn}, 198.10$ ppm Cu, 1,368 ppm Zn, 3.34 ppm Co, 4.69 ppm Mo, $48 \mathrm{ppm}$ B was used as a treatment. Plotting the experiment was conducted after plowing the soil of $3,200 \mathrm{~m}^{2}$. There were 12 rows with distance of interrow was $100 \mathrm{~cm}$. Stems were planted in two rows system (one row contains two stems) with approximately $100 \times 100 \mathrm{~cm}$. Each row contents of 160 hole of stem

Treatments were arranged by factorial (2x2) in completely randomized block design (CRBD) with 3 reps used as block. First factor was two levels of $\mathrm{KCl}, 200$ and $300 \mathrm{~kg} \mathrm{KCl} / \mathrm{ha}$. Second factor was two levels of micro nutrient, 0 and $20 \mathrm{~kg}$ micro nutrient/ha. As many as four samples of plants were taken from each treatment. Firts fertilizer of $200 \mathrm{~kg}$ urea, $150 \mathrm{~kg}$ TSP and 200 $\mathrm{kg} \mathrm{KCl} / \mathrm{ha}$ was applied at $1 \mathrm{MAP}$. The rest of $100 \mathrm{~kg} \mathrm{KCl} / \mathrm{ha}$ was applied at $4 \mathrm{MAP}$ as treatment of $300 \mathrm{~kg} \mathrm{KCl} / \mathrm{ha}$. The application of $20 \mathrm{~kg}$ mico nutrient/ha was together with $100 \mathrm{~kg} \mathrm{KCl} / \mathrm{ha}$ as treatment. The fertilizers were applied in each cassava plant, consequently every plant would be applied by $32.5 \mathrm{~g}$ urea, $24.4 \mathrm{~g}$ TSP, $\mathrm{KCl}$ according to treatment $(32.5 \mathrm{~g}$ for $200 \mathrm{~kg} \mathrm{KCL} / \mathrm{ha}$ and $48.75 \mathrm{~g}$ for $300 \mathrm{~kg} \mathrm{KCl} / \mathrm{ha}$ ), micro nutrient according to treatment (without micro nutrient and $3.25 \mathrm{~g}$ for $20 \mathrm{~kg}$ micro nutrient/ha). The fertilizers were applied in hole with the distance of $10 \mathrm{~cm}$ from the cassava plant.

Variables observed in this study were plant height, leaf number, stem diameter, leaf greeness, stem dry weight, leaf dry weight, fresh root weight, skin fresh weight, root number, and starch. Starch content was calculated by using equipment of Thai Sang 
Metric co. Ltd. All variables in this study were evaluated at seven and 10 MAP.

Data was analyzed by anova after fulfilling of two asumptions, as homogenous variance by Bartlett test and additive model by Tukey test with program of SAS-9.2. The difference of mean values was analyzed by $5 \%$ LSD.

\section{RESULT AND DISCUSSION}

Some variables observed in this study showed highly variation due mainly to potassium, as plant height, leaf number at 10 MAP, and leaf dry weight at 10 MAP. Moreover, application of micro nutrient could induce variation in plant height, stem diameter at $10 \mathrm{MAP}$, leaf dry weight at 10 MAP, and skin fresh weight at 7 MAP (Table 1).

Table 1. Mean square values of plant height, leaf number, stem diameter, stem dry weight, leaf dry weight, root fresh weight, skin fresh weight, root number, and starch content

\begin{tabular}{|c|c|c|c|c|c|}
\hline Variabel & $\mathrm{KCl}$ & M & $\mathrm{KCl} \times \mathrm{M}$ & Error & $\mathrm{CV}(\%)$ \\
\hline PH-7 MAP (cm) & $1,810.98 * *$ & $38,653.63^{* *}$ & $8,345.91 * *$ & 916.27 & 13.77 \\
\hline PH-10 MAP (cm) & $2,872.67 * *$ & $25,868.61 * *$ & $41,101.57 * *$ & $1,664.96$ & 14.87 \\
\hline LN-7 MAP (no,) & $2,067.19$ & $6,888.02$ & $5,187.52$ & $5,187.52$ & 55.03 \\
\hline LN-10 MAP (no.) & $7,726.69^{*}$ & $3,350.02$ & $4,162.69$ & $1,858.47$ & 67.82 \\
\hline SD-7 MAP (mm) & 1.24 & $189.79 * *$ & 42.49 & 12.13 & 15.57 \\
\hline SD-10 MAP (mm) & 6.57 & $209.31 * *$ & $95.33 *$ & 14.30 & 15.61 \\
\hline SDW-7 MAP (g) & $7,237.34$ & $39,090.67$ & $5,954.11$ & $1,810.45$ & 18.46 \\
\hline SDW-10 MAP (g) & $23,470.21$ & $1,000,634.25$ & $745,456.90^{*}$ & $113,373.41$ & 52.21 \\
\hline LDW-7 MAP (g) & $9,042.03$ & $2,112.05$ & $1,624.01$ & $5,110.11$ & 54.55 \\
\hline LDW-10 MAP (g) & $535.34 * *$ & $273.13 *$ & $346.15^{* *}$ & 38.21 & 75.79 \\
\hline RFW-7 MAP (g) & $853,333.33$ & $750,000.00$ & $213,333.33$ & $118,888.89$ & 20.09 \\
\hline RFW-10 MAP (g) & 1.02 & $3,686,480.50$ & $3,020.96$ & $1,316,857.39$ & 59.47 \\
\hline SFW-7 MAP (g) & $28,726.31$ & $9,839.85^{*}$ & $20,429.06^{*}$ & $6,898.37$ & 25.59 \\
\hline SFW-10 MAP (g) & $12,444.50$ & 78.48 & $1,272.31$ & $2,999.04$ & 19.35 \\
\hline RN-7 MAP (no.) & 27.00 & 27.00 & 40.33 & 12.69 & 25.76 \\
\hline RN-10 MAP (no.) & 2.08 & 0.97 & 0.54 & 5.33 & 45.95 \\
\hline SC-7 MAP (\%) & 4.08 & 4.08 & 4.08 & 2.25 & 10.06 \\
\hline SC-10 MAP (\%) & 0.52 & 4.69 & 2.52 & 2.74. & 9.81 \\
\hline \multicolumn{6}{|c|}{ 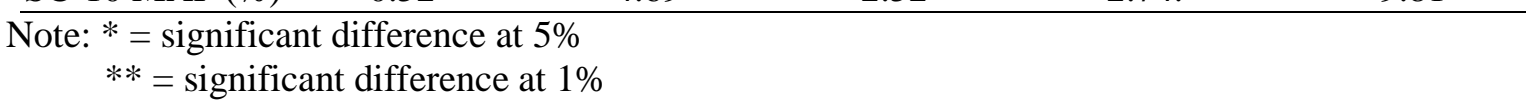 } \\
\hline $\begin{array}{l}\mathrm{PH}=\text { plant hei } \\
\mathrm{SD}=\text { stem dia } \\
\mathrm{M}=\text { micro nut } \\
\mathrm{RFW}=\text { root } \mathrm{fr} \\
\mathrm{SC}=\mathrm{starch} c \mathrm{co} \\
\mathrm{KCl} \times \mathrm{M}=\text { int }\end{array}$ & $\begin{array}{l}\text { ht } \\
\text { heter } \\
\text { ent } \\
\text { sh weight } \\
\text { tent }\end{array}$ & $\begin{array}{l}\text { LN } \\
\text { RN } \\
\text { MAP } \\
\text { SFW }\end{array}$ & $\begin{array}{l}=\text { leaf numb } \\
=\text { root numb } \\
=\text { month afte } \\
=\text { skin fresh }\end{array}$ & planting & \\
\hline
\end{tabular}


Table 2. The different mean values of plant height, stem diameter, stem dry weight, leaf dry weight due to application of $\mathrm{KCl}$ and micro nutrient by LSD with 5\% level of significant different

\begin{tabular}{|c|c|c|c|c|c|c|c|c|c|}
\hline \multirow{3}{*}{\multicolumn{2}{|c|}{$\begin{array}{c}\mathrm{KCl} \quad \mathrm{M} \\
(\mathrm{kg} / \mathrm{ha})\end{array}$}} & \multicolumn{4}{|c|}{7 MAP } & \multicolumn{4}{|c|}{$10 \mathrm{MAP}$} \\
\hline & & \multirow{3}{*}{$\begin{array}{c}\text { PH } \\
--\mathrm{cm}-- \\
253.7 \mathrm{a}\end{array}$} & \multirow{3}{*}{$\begin{array}{c}\begin{array}{c}\text { SD } \\
--\mathrm{mm}--\end{array} \\
21.3 \mathrm{a}\end{array}$} & \multirow{3}{*}{$\begin{array}{c}\text { SDW } \\
--- \\
126.5 a\end{array}$} & \multirow{2}{*}{ LDW } & \multirow{3}{*}{$\begin{array}{c}\begin{array}{c}\mathrm{PH} \\
--\mathrm{cm}--\end{array} \\
305.5 \mathrm{a}\end{array}$} & \multirow{3}{*}{$\begin{array}{c}\begin{array}{c}\text { SD } \\
-- \\
\text { mm -- }\end{array} \\
26.4 \mathrm{a}\end{array}$} & \multirow{2}{*}{\multicolumn{2}{|c|}{$\begin{array}{r}\text { SDW } \\
\quad--- \text { g }-- \\
\end{array}$}} \\
\hline & & & & & & & & & \\
\hline 20 & 20 & & & & $18.7 \mathrm{a}$ & & & 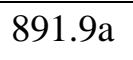 & $5.12 b$ \\
\hline 200 & 0 & $2.5 \mathrm{c}$ & $26.4 \mathrm{a}$ & $285.2 \mathrm{a}$ & $12.0 \mathrm{a}$ & $229.1 \mathrm{c}$ & $21.3 \mathrm{c}$ & $353.9 \mathrm{~b}$ & $4.52 \mathrm{~b}$ \\
\hline 300 & 20 & $25.7 \mathrm{~b}$ & $24.0 \mathrm{a}$ & $220.2 \mathrm{a}$ & $12.0 \mathrm{a}$ & $274.1 \mathrm{~b}$ & $24.9 \mathrm{ab}$ & $686.8 \mathrm{a}$ & $6.43 b$ \\
\hline 300 & 0 & $03.9 \mathrm{c}$ & $24.9 \mathrm{a}$ & $289.8 \mathrm{a}$ & $12.7 \mathrm{a}$ & $285.2 \mathrm{ab}$ & $24.0 \mathrm{~b}$ & $647.3 \mathrm{a}$ & $16.6 \mathrm{a}$ \\
\hline \multicolumn{2}{|c|}{$\operatorname{LSD}(5 \%)$} & 20.6 & 5.26 & 163.5 & 7.12 & 27.7 & 2.30 & 231.2 & 9.23 \\
\hline
\end{tabular}

Note: Values in the same colomn followed by the same letter indicated not significantly different by LSD with $5 \%$ level of significant difference

$\mathrm{PH}=$ plant height; $\mathrm{SD}=$ stem diameter; $\mathrm{SDW}=$ stem dry weight; LDW= leaf dry weight, 7 MAP and 10 $\mathrm{MAP}=$ seven and ten months after planting; $\mathrm{M}=$ micro nutrient

Interestingly, high variations of plant height, stem diameter at 10 MAP, stem dry weight at 10 MAP, leaf dry weight at 10 MAP, and skin fresh weight at 7 MAP were affected by both potassium and micro nutrient applications. It seems that both potassium and micro nutrient could induce the variation in growth variabels. However, potassium and micro nutrients could not influence the variation of root components, as root number, root weight, and starch content. The result showed that the balanced nutrients was achieved for vegetative growth and not for root growth. Imakumbili et al. (2019) showed the result of cassava growth and nutrient sufficency that was conducted in Tanzania. They reported that the optimum cassava growth could be achieved by balanced nutrients both micro and micro nutrients.

The variables of plant height showed significantly high applied by $200 \mathrm{~kg} \mathrm{KCl} / \mathrm{ha}$ and $20 \mathrm{~kg}$ micro nutrient/ha at both ages, 7 and 10 MAP (Table 2). This means that potassium and micro nutrient sinergily induce the plant height of cassava. This result was different from the the result studied by Adekayode and Adeola (2009) which reported that cassava yield increased from 20.8 ton/ha by $120 \mathrm{~kg} \mathrm{~K}_{2} \mathrm{O}$ to 22.9 ton/ha by $150 \mathrm{~kg} \mathrm{~K} \mathrm{~K}_{2} \mathrm{O}$. They also reported that high cassava yield was due mainly to reduction of $\mathrm{K}$ soil to export to cassava plant, especially root. Moreover, the reduction of leaf dry weight from 7 MAP to 10 MAP was probably due to the reduction of leaf number except for $300 \mathrm{~kg} \mathrm{KCl} / \mathrm{ha}$ treatment. It seems that the treatment of $300 \mathrm{~kg} \mathrm{KCl} / \mathrm{ha}$ could maintain the leaf fall. Fernandes et al. (2017) supported that the appllication of K could increase the dry matter of plant around $43 \%$. On the other hand, Rosas et al. (1976) hypothesized that a high rate of leaf fall is not associated with a large root capacity, leaving the way open for the production of varieties with both large root-producing potential and good leaf. This means that high dry matter is not associated with high production of cassava root.

The application of $200 \mathrm{~kg} \mathrm{KCl}$ and 20 $\mathrm{kg}$ micro/ha could make plant height higher at $7 \mathrm{MAP}$ and also at $10 \mathrm{MAP}$, this result was concomittent with the result of Chua at al. (2020) who reported that the higher K application, the higher plant would be. Howeler and Asher (1982) also reported that the application of micro nutrient on low certain concentration could increase dry 
matter. This implies that potassium and micro nutrients could induce dry matter of cassava in certain level of application. This is proven that the total of stem dry weight and leaf dry weight applied by $200 \mathrm{~kg} \mathrm{KCl}$ and $20 \mathrm{~kg}$ micro/ha was heavier than the other treatments applied in this study.

\section{CONCLUSION}

It was concluded that the application of potassium (200 kg KCl/ha) and micro nutrients (20 kg zincmicro /ha) could induce the variation of vegetative growth as, plant height and stem dry weight. Consequetly, the total of shoot dry matter could be increased by the application of $200 \mathrm{~kg}$ $\mathrm{KCl} / \mathrm{ha}$ and $20 \mathrm{~kg}$ zincmicro/ha. The incease of stem dry weight would not be followed by the increase in cassava production both root weight and starch content.

\section{ACKNOWLEDGEMENTS}

We would like to thank to Sungai Budi Group, Cassava Industry giving opportunity to conduct the research to characterize and identify cassava starch in Tanjung Bintang region of South Lampung. Respectful appreciation is also addressed to Jurnal Agrotropika published by University of Lampung for nice help and support in publishing our manuscrips.

\section{REFERENCES}

Adekayode, F and O.F. Adeola. 2009. The response of cassava to potassium fertilizer treatments. Journal of Food, Agriculture \& Environment, 7 (2): 279-282.

Agbaje, G. O. and T. A. Akinlosotu. 2004. Influence of NPK fertilizer on tuber yield of early and late-planted cassava in a forest alfisol of south-western Nigeria. African Journal of Biotechnology, 3(10): 547-551.

Apea-Bah, F.B., I. Oduro, W.O. Ellis and O. Safo-Kantanka. 2011. Factor analysis and age at harvest effect on the quality of flour from four cassava varieties. World J. of Dairy \& Food Sci. 6 (1): 43-54.

Baafi, E. and O. Safo-Kantanka. 2007. Effect of genotype, age, and location on cassava starch yield and quality. J. of Agron. 6 (4): 581-585.

BPS. 2018. Produksi Ubikayu Menurut Provinsi (ton), 1993-2017 (https://www.bps.go.id/linkTableDinamis /view/id/880).

Chua, M.F., L.Youbee, S. Oudthachit, P. Khanthavong, E.J. Veneklaas, and A.I. Malik. 2020. Potassium fertilisation is required to sustain cassava yield and soil fertility. Agronomy, (10): 2-11.

Fernandes, A.M., B. Gazola, J. G. da Silva Nunes, E.L. Garcia and M. Leonel. 2017. Yield and nutritional requirements of cassava in response to potassium fertilizer in the second cycle. J. of Plant Nutrition, 40:1-31.

Howeler, R.and C.J. Asher. 1982. Micronutrient deficiencies and toxicities of cassava plants grown in nutrient soultion. I. Critical tissue concntrations. J. of Plant Nutrition.

ImakumbiliI, M.L.E., G. Mkamilo, E. Semu, J.M.R. Semoka, and A. Abass. 2019. Soil nutrient adequacy for optimal cassava growth, implications on cyanogenic glucoside production: A case of konzoaffected Mtwara region, Tanzania. Plos One, 14 (5): 1-17.

Kayode, G.O. 1983. Effects of various planting and harvesting times on the yield, $\mathrm{HCN}$, dry-matter accumulation and starch content of four cassava varieties in a tropical rainforest region. The J. of Agric. Sci. 101 (3): 633-636.

Prammanee S., K. Kamprerasart, S. Salakan, and K. Sriroth. 2010. Growth and starch content evaluation on newly released cassava cultivars, Rayong 9, Rayong 7 and Rayong 80 at different harvest times. Kasetsart J.Nat Sci. 44: 558-563.

Rosas, C., J.H. Cock, and G. Sandoval. 1976. Leaf fall in cassava. Expl Agric. 12: 395400. 
You, Z.L., J. Zhao, S. Wu, X. Fan, X. Luo and B. Chen. 2016. Characters related to higher starch accumulation in cassava storage roots. Scientific Reports, 6:19823. DOI: $10.1038 /$ srep19823.
Zhu, F. 2014. Composition, structure, physicochemical properties, and modifications of cassava starch. Carbohydrate Polymers, 122: 456-480. 